\title{
Oil Price and Stock Market: Empirical Evidence from Nigeria
}

By

\author{
Akinlo Olayinka Olufisayo ${ }^{1}$
}

\begin{abstract}
This paper examined the relationship between changes in oil prices and stock market growth over the period 1981-2011 using vector error correction modeling approach. The results suggest a long run relationship between oil price, exchange rate and stock market growth. A unidirectional causality runs from oil price change to stock market development. The impulse response function shows that oil price has a temporary positive impact on stock market. The VDC shows that stock market development to be very much dependent on shock on oil price change.
\end{abstract}

Keywords: oil price, stock market, VECM, Nigeria

\section{Introduction}

Several studies have examined the relationship between oil price changes and macroeconomic activities. Many of these studies have indeed showed that oil price changes had significant effects on domestic price level, gross domestic product, investment and savings (Crunado and Garcia 2005, Kilian 2008 and Cologne and Manera, 2008). However, not many studies have been done on the relationship between oil price changes and stock market in general and especially in sub Saharan Africa countries. Very few studies that have examined the interaction between oil price changes and stock markets are mainly on few industrialized net oil-importing countries such as the USA, UK and Japan (Jones and Kaul 1996; Sadorsky, 1999). There, is therefore, the need to examine the interaction between oil price changes and stock market in oilexporting developing countries like Nigeria. The use of Nigeria as a case study is interesting for many reasons. One, Nigeria is the largest exporter of oil in Africa. Two, the Nigerian stock market is a highly promising area for international portfolio diversification. Three, several major reforms have implemented recently in almost all the sectors of the economy. The remainder of the paper is arranged as follows: section 2 provides a review of previous empirical studies. Section 3 describes the data and 
empirical methodology adopted in this study. Section 4 reports the estimation results. Finally, section concludes the paper.

\section{Literature Review}

Several studies have examined the nexus of relationship between oil price changes and macroeconomic fundamentals such as gross domestic product, inflation, employment, exchange rate and investment (Chen and Chen, 2007, Huang and Guo, 2007 and Nandha and Hammoudeh 2007). However, only very few studies have focused on the interaction between oil price changes and stock market especially in developing countries like Nigeria.

The study by Jones and Kaul (1996) examined the reaction of international stock markets for oil price shocks. The study found that, in the postwar period, the reaction of US and Canadian stock prices to oil shocks can be completely accounted for by the impact of these shocks on real cash flows. However, the results for Japan and the Uk were inconclusive.

The study by Huang, et al. (1996) examined the link between daily oil future returns and daily US returns using an unrestricted vector autoregressive (VAR) approach. The study showed that oil returns do lead some individual oil company stock returns, but oil future returns do not have much impact on general market indices. The study by Sadorsky (1999) examined the relationship between oil changes and aggregate stock returns using American monthly data. The results from VAR with GARCH approach showed that oil price and its volatility both play important roles in affecting real stock returns. The results showed that oil price movements after 1986 accounted for a larger fraction of the forecast error variance in real stock returns that did interest rates. The study by Pappetrou (2001) based on VAR approach examined the interaction amongst oil prices, real stock prices, interest rates, real economic activity and employment in Greece. The results showed that oil price changes affect real economic activity and employment. Moreover, oil prices explained a significant movement in stock price. Hong et al. (2002) provided evidence of a negative association between oil price returns. In the same way, the study by O'Neil et al. (2008) and Park and Ratti (2008) found that oil price shocks have a statistical significant negative effect on stock prices for an extended sample of thirteen developed markets.

The study by Boyer and Filion (2007) found that Canadian energy stocks are positively associated to the overall markets return and the appreciations of crude oil and natural gas prices. The study by Miller and Ratti (2009) looked at the relationship between the world price of oil and international stock markets. The results of the analysis showed that stock market indices responded negatively to increases in the oil price in the long run. However, according to them, this pattern appeared to disintegrate from the beginning of 2000. The results from Lescaroux and Mignon (2008) study shocked a strong unidirectional causality running from oil prices to share prices, most especially for oil exporting countries.

The studies by Gogineni (2007) and Yurtsever and Zahor (2007) supported the finding that oil prices are positively associated with stock prices where oil price shocks reflect changes in aggregate demand. However, the relationship would be negative where oil 
price shocks reflect in aggregate supply. Aside, the results showed that stock prices respond symmetrically to changes in oil prices, while lower oil prices are not associated with higher oil.

The study by Hammoudeh and Aleisa (2004) showed that there was a bidirectional relationship between Saudi sock returns and oil price changes. Basher (2006) using VAR analysis for Gulf cooperation countries found that only the Saudi and Omani markets have predictive power of oil price increase. Chen (2010) suggested then an increase in oil prices led to a higher probability of a bear market emerging. Bhar and Nikolova (2010) found that global oil price returns have significant impact on Russian equity returns and volatility.

The study by Hasan and Mahbobi (2013) on the influence of oil prices on Canadian stock market showed that the impact of oil price on the Canadian stock market has been robustly increasing the second period. The empirical analysis by Lin et al. (2011) showed that the impact of oil price shocks on Greater China has been mixed. The effect in Taiwan's stock market was very similar to that in the US stock market. Finally, the results showed that all the three shocks had significant positive impacts on Hong Kong's stock return.

\section{Data and Methodology}

The paper uses annual data on oil price, stock market capitalization and exchange rate. The oil price adopted is US \$ per barrel and stock market development is proxied as market capitalization. Exchange rate is the Nigerian Naira exchange rates against US Dollars. The study adopts vector Autoregressive (VAR) technique. The basic model employed in the study can be expressed as:

$$
\begin{aligned}
& M k t_{t}=\beta_{0}+\beta_{1} \mathrm{OIP}_{t}+ \\
& \beta_{2} E C_{t}+\mu_{t} \ldots \ldots \ldots \ldots \ldots
\end{aligned}
$$

Where $\mathrm{Mkt}_{\mathrm{t}}$ is the market capitalization, OIP is the oil price and EXC is the Nigerian naira/US Dollar exchange rate. The data were sourced from the Central Bank of Nigeria, statistical Bulletin.

The series were tested for stationarity using Augmented Dickey-Fuller and Phillips-Peron method. If the series are integrated of the same order, then, there is a possibility for cointegration of the variables, with a test for cointegration being meaningful.

After ascertaining that both series are integrated of the same order, then one can proceed to test for cointegration using Johansen maximum Likelihood procedures Johansen and Juselius (1990)]. Any long term cointegration found between the series will contribute an additional error-correction term to the Error Correction model. The Johansen procedure in a vector Autoregressive (VAR) based test on restriction imposed by cointegration in the unrestricted VAR. The null hypothesis in consideration is $\mathrm{H}_{0}$, that there are a different number of cointegration, relationship, against $\mathrm{H}_{1}$, that all series in the VAR are stationary. 
The VECM adopted in this paper is specified as :

$$
\begin{aligned}
& \Delta M K T_{t}=\lambda_{1}+\sum_{i=1}^{k-1} \delta_{1 i} \Delta M K T_{t-i}+\sum_{i=1}^{k-1} \theta_{1 i} \Delta O I P_{t-i}+\sum_{i=1}^{k-1} \Psi_{1 i} \Delta E X C_{t-i}+ \\
& \mu_{1} E C T_{t-1}+\varepsilon_{t} \ldots \ldots(2) \\
& \Delta O I P_{t}=\lambda_{2}+\sum_{i=1}^{k-1} \delta_{2 i} \Delta M K T_{t-i}+\sum_{i=1}^{k-1} \theta_{1 i} \Delta O I P_{t-i}+\sum_{i=1}^{k-1} \Psi_{2 i} \Delta E X C_{t-i}+ \\
& \mu_{2} E_{C T T_{t-1}}+\varepsilon_{t} \ldots \ldots(3) \\
& \Delta E X C_{t}=\lambda_{3}+\sum_{i=1}^{k-1} \delta_{3 i} \Delta M K T_{t-i}+\sum_{i=1}^{k-1} \theta_{3 i} \Delta O I P_{t-i}+\sum_{i=1}^{k-1} \Psi_{3 i} \Delta E X C_{t-i}+ \\
& \mu_{3} E C T_{t-1}+\varepsilon_{t} \ldots \ldots(4)
\end{aligned}
$$

The coefficient of the $\mathrm{ECT}_{\mathrm{t}-1}$ term infers long run causality, while the joint f-test of the coefficients of the first differenced independent variables indicates short run. The causality can be derived through the Wald test of the joint significance of the lags of the independent variables.

To examine the relationship among economic variables, innovation accounting (variance decomposition and impulse response function) technique can be applied in the analysis.

\section{Empiricaal Results}

\section{Basic statistics description and stationary test}

From table 1, all the series display a high level of consistency as their mean and median values are perpetually within the maximum and minimum values of the series. From the series skewness and kurtosis, we see that the data have that tail properties. Finally, the probability that the Jarque-Bera statistic exceed (in absolute value) the observed value is generally low suggesting the rejection of the hypothesis of normal distribution.

Table 1: Descriptive Statistics

\begin{tabular}{llll}
\hline & MKT & OIP & EXC \\
\hline Mean & 2078.468 & 35.83871 & 67.41402 \\
Median & 262.6000 & 27.80000 & 81.25280 \\
Maximum & 13294.60 & 100.0000 & 153.8600 \\
Minimum & 5.000000 & 10.60000 & 0.610000 \\
Std. dev. & 3733.599 & 25.73688 & 58.86975 \\
Skewness & 1.782650 & 1.459453 & 0.068403 \\
Kurtosis & 4.799508 & 3.917995 & 1.325106 \\
& & & \\
Jarque-Bera & 20.60155 & 12.09352 & 3.647649 \\
Probability & 0.000034 & 0.002366 & 0.161407 \\
& & & \\
Sum & 64432.50 & 1111.000 & 2089.835 \\
Sum Sq. Dev. & $4.18 \mathrm{E}+08$ & 19871.60 & 103969.4 \\
Observations & 31 & 31 & \\
& & &
\end{tabular}


From table 2, the results of the ADF and KPSS tests show that all the variables are integrated of order one or $\mathrm{I}(1)$.

Table 2: Unit Root Test

\begin{tabular}{|l|l|l|l|l|}
\hline & \multicolumn{2}{|l|}{ ADF } & \multicolumn{2}{l|}{ KPSS } \\
\hline & LEVEL & $\begin{array}{l}\mathbf{1}^{\text {ST }} \\
\text { Difference }\end{array}$ & Level & $\mathbf{1}^{\text {st }}$ difference \\
\hline MKT Constant & -0.264 & -3.829 & 1.607 & 0.139 \\
\hline Constant \& Linear & -2.885 & -3.724 & 0.159 & 0.110 \\
\hline OIP Constant & -0.154 & -4.379 & 0.713 & 0.409 \\
\hline Constant \& Linear & -1.289 & -5.669 & 0.370 & 0.036 \\
\hline EXC Constant & -2.276 & -3.274 & 1.474 & 0.490 \\
\hline Constant \& Linear & -0.531 & -4.444 & 0.386 & 0.079 \\
\hline
\end{tabular}

Note: Table 3 presents the results of the cointegration test. The lag length of the cointegration test is selected by nonautocorrelation of the error term. Thus the optimal lag length that was selected is 1(i.e lag =1). According to the results based on Johansen's test, the null hypothesis of no cointegration $(r=0)$ can be rejected using the trace test.

Table 3: Johansen Cointegration Test (with a linear Trend) where $r$ is the number of cointegrating vectors

\begin{tabular}{llllll}
\hline Null & Alternative $\mathrm{r}$ & $\lambda-\max$ & Critical value & Trace & Critical value \\
\hline $\mathbf{O}$ & 1 & 21.03 & 21.13 & 34.07 & $29.79 * *$ \\
$\mathbf{\leq} 1$ & 2 & 12.70 & 14.26 & 13.03 & 15.49 \\
$\mathbf{\leq} 2$ & 3 & 0.33 & 3.84 & 0.33 & 3.84 \\
\hline
\end{tabular}

The Granger causality results are presented in table 4 for the long-run Granger causality, the results suggest that one period lagged error-correction term, $E C T_{t-1}$ has a negative sign and is statistically significant at 5 per cent level when stock market development (MK'T) stands as dependent variable. This shows that stock market has bilateral causal relationship with oil price changes. The results in table 4 show unidirectional causality running from oil price changes to stock market development. Moreover, the results show unidirectional causality from stock market to exchange rate.

Table 4: Granger Causality and error Correction Model

\begin{tabular}{|c|c|c|c|c|}
\hline \multirow[b]{2}{*}{ Variables } & \multicolumn{3}{|c|}{ Chi-square statistics } & \multirow{2}{*}{$\begin{array}{l}\mathrm{ECT}_{\mathrm{t}-1} \\
\text { (t-statistics) }\end{array}$} \\
\hline & $\Delta \mathrm{MKT}_{\mathrm{t}}$ & $\mathrm{OIP}_{t}$ & $\mathrm{EXC}_{\mathrm{t}}$ & \\
\hline$\Delta \mathrm{MKT}_{\mathrm{t}}$ & -- & $\begin{array}{l}10.92^{* * *} \\
(0.004)\end{array}$ & $\begin{array}{l}0.38 \\
(0.83)\end{array}$ & $\begin{array}{l}-0.747 * * \\
(-2.09)\end{array}$ \\
\hline$\Delta \mathrm{OIP}_{\mathrm{t}}$ & $\begin{array}{l}3.04 \\
(0.22)\end{array}$ & -- & $\begin{array}{l}0.01 \\
(0.99)\end{array}$ & $\begin{array}{l}0.004^{* *} \\
(2.76)\end{array}$ \\
\hline$\Delta \mathrm{EXC}_{\mathrm{t}}$ & $\begin{array}{l}6.40 * * \\
(0.04)\end{array}$ & $\begin{array}{l}0.29 \\
(0.86)\end{array}$ & -- & $\begin{array}{l}0.004 \\
(1.41)\end{array}$ \\
\hline
\end{tabular}

Note: *** and ${ }^{* *}$ denote significant at $1 \%$ and $5 \%$ respectively.

Figure 4 shows the results of the impulse responses of the variables to one standard deviation of shock to each of the variables in the system. In this study, we focus on the responses of stock market development (MKT) to one standard deviation of shock to oil price and vice versa. From the impulse responses shown in table 4, we found that oil price has a temporary positive impact on stock market development. A positive shock on 
oil price increases stock market development for the first three periods. It falls in the medium term but increases marginally in the long run period. On the other hand, oil increases steadily throughout in response to a positive shock on stock market capitalization. Stock market development respond negatively to a shock on exchange rate while stock market initially responds negatively to a shock ion exchange rate but turns positive in the $2^{\text {nd }}$ to $4^{\text {th }}$ period. It however becomes constant afterwards.
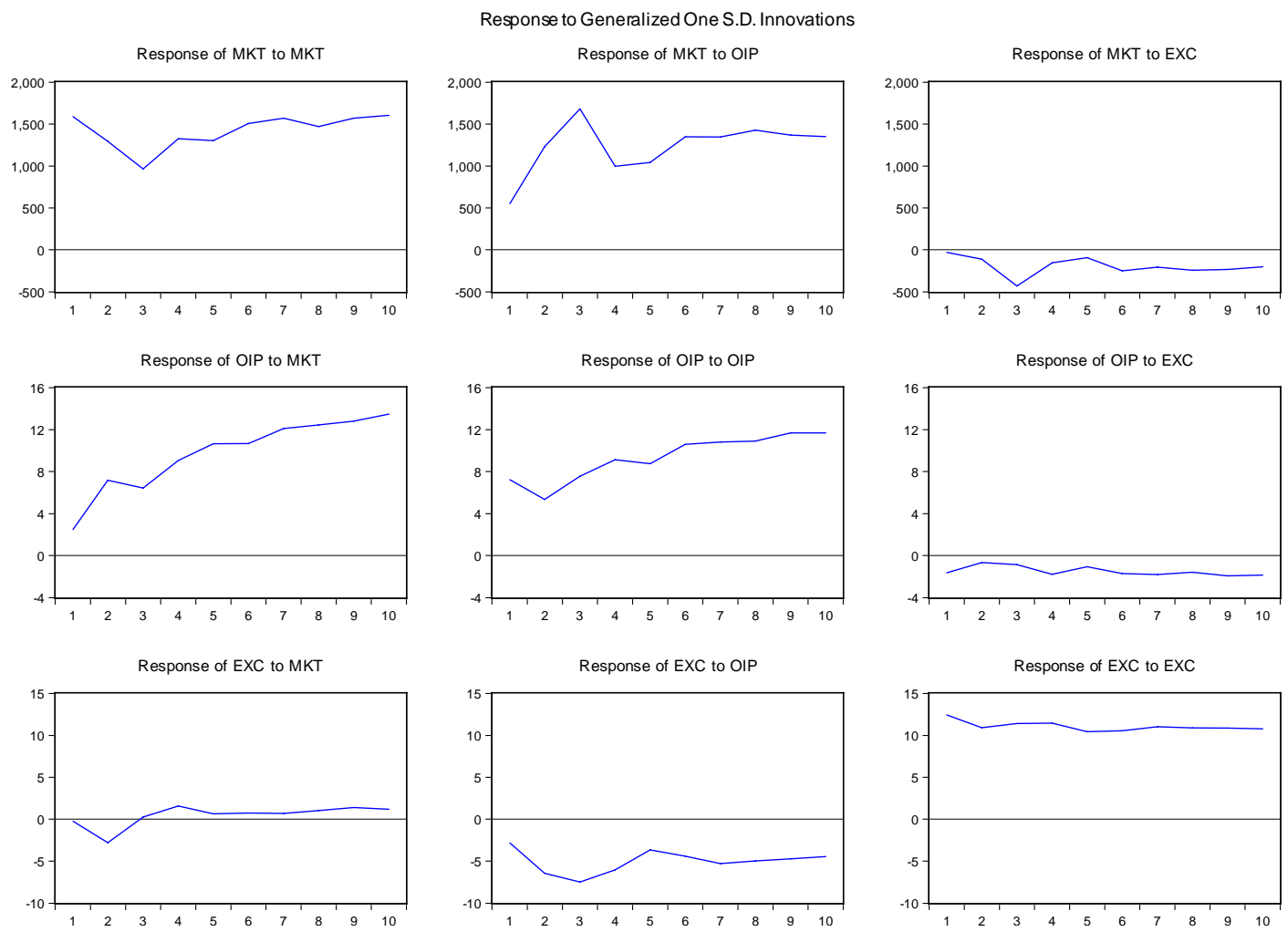

Fig. 1: Plot of the Impulse Response function

Table $5 \mathrm{a}$ and $5 \mathrm{~b}$ shows the variance decompositions of stock market development (MKT) and oil price (OIP). The evidence shows stock market development (MKT) to be very mush dependent on shock oil price changes. Except for $1^{\text {st }}$ and $2^{\text {nd }}$ periods, oil prices changes explained over 25 per cent of the shocks on stock market development. This is in line with the Granger causality results where stock market development is endogeneous. Table $5 \mathrm{~b}$ shows the variance decomposition of the oil price. The results show that oil price is very much dependent on shocks to stock market development. All through the periods, stock market is found to significantly contribute to the shocks on oil price changes.

Table 5a: Variance decomposition of MKT

\begin{tabular}{|l|l|l|l|l|}
\hline Period & S.E. & MKT & OIP & EXC \\
\hline 1 & 1588.522 & 100.0000 & 0.000000 & 0.000000 \\
\hline
\end{tabular}




\begin{tabular}{|l|l|l|l|l|}
\hline 2 & 2214.740 & 85.60302 & 14.14340 & 0.253578 \\
\hline 3 & 2811.246 & 64.90611 & 34.85702 & 0.236866 \\
\hline 4 & 3159.797 & 68.91746 & 30.89474 & 0.187806 \\
\hline 5 & 3476.633 & 70.99377 & 28.79925 & 0.206977 \\
\hline 6 & 3889.693 & 71.68418 & 28.14905 & 0.166764 \\
\hline 7 & 4280.970 & 72.63424 & 27.22547 & 0.140297 \\
\hline 8 & 4630.295 & 72.14288 & 27.73618 & 0.120933 \\
\hline 9 & 4967.525 & 72.66917 & 27.22575 & 0.105080 \\
\hline 10 & 5288.470 & 73.32064 & 26.58394 & 0.095419 \\
\hline
\end{tabular}

Table $5 \mathrm{~b}$ Variance Decomposition of OIP

\begin{tabular}{|l|l|l|l|l|}
\hline Period & S.E. & MKT & OIP & EXC \\
\hline 1 & 7.222677 & 12.00521 & 87.99479 & 0.000000 \\
\hline 2 & 10.63011 & 51.05357 & 48.91161 & 0.034813 \\
\hline 3 & 13.68623 & 53.01575 & 46.75794 & 0.226306 \\
\hline 4 & 17.60159 & 58.45853 & 41.39933 & 0.142140 \\
\hline 5 & 21.26971 & 65.07306 & 34.79257 & 0.134372 \\
\hline 6 & 24.90297 & 65.79214 & 34.10170 & 0.106164 \\
\hline 7 & 28.56332 & 67.89909 & 32.01971 & 0.081200 \\
\hline 8 & 31.94156 & 69.46431 & 30.46185 & 0.073842 \\
\hline 9 & 35.26637 & 70.15009 & 29.78781 & 0.062105 \\
\hline 10 & 38.48925 & 71.15016 & 28.79593 & 0.053912 \\
\hline
\end{tabular}

\section{Conclusion}

The relationship between oil price change and stock market has been preoccupied the attention of economists in recent times. This paper analyses the nexus of relationship between oil price and stock market using vector error correction modeling approach. The results show that oil price, exchange rate and stock market development are cointegrated. The results from Granger Causality test show that there is unidirectional causality from oil price change to stock market development. Also, unidirectional causality from stock market to exchange rate was found. The IRFs show that oil price increases steadily over the long run in response to a positive shock on stock market growth. However, oil price has a temporary positive impact on stock market growth. The VDCs show stock market growth to be dependent on oil price change. Also, oil price is highly dependent on shocks to stock market development.

\section{References}

Basher, Z. (2006) "Wild Oil Prices, but Brave Stock Markets! The Case of Gulf Cooperation Council (GCC) Stock markets", Middle East Economic Association Conference, Dubai.

Bhar, R. and B. Nikolova (2010) "Global Oil Prices, Oil Industry and Equity Returns: Russian Experience", Scottish Journal of political Economy, vol.57 (2), p. 169-186.

Boyer, M. M. and Filion, D. (2007) "Common and Fundamental Factors in Stock Returns of Canadian Oil and Gas Companies", Energy Economics, vol. 2993 0, p. 428-453.

Chen, S. S. (2010) "Do Higher Oil Prices Push the Stock Market in to Bear Territory?", Energy Economics, vol. 32(2), p. 490-495. 
Chen, S.S. and H.C. Chen (2007) “Oil Prices and Real Exchange Rates", Energy Economics, vol.29, p. 390-404.

Cologne, A. and Manera, M. (2008) "Oil Prices, Inflation and Interest Rates in a Structural Cointegrated VAR Model for the G-7 countries", Energy Economics, vol. 30, p. 856-888.

Cunado, J. and F.P. Garcia (2005) "Oil Prices, Economic Activity and Inflation: Evidence for some Asian Countries", Quarterly Review of Economics and Finance, vol. 45, p. 65-83.

Cunado, J.and Perez de Garcia, F. (2005) "Oil Prices, Economic Activity and Inflation: Evidence for Some Asian Countries", The Quarterly Review of Economics and Finance, vol. 45(1), p. 65-83.

Gogineni, S. (2007) "The Stock Market Reaction to Oil Price Changes”, University of Oklahoma Working Papers.

Hammoudeh, S. and Alesia, E. (2004) "Dynamic Relationship among GCC Stock markets and NYMEX Oil Futures", Contemporary Economic Policy, vol. 22, p. 250-269.

Hassan, S and M. Mohbobi (2013) "The increasing influence of oil prices on the Canadian Stock market", The Journal of Business and Finance Research, vol. 7(3), p.27-39.

Hong, H., W. Torous and R. Valkanov (2002) "Do Industries lead the Stock Market? Gradual Diffusion of Information and Cross-asset Return Predictability", Working Paper, Stanford university and ULCA.

Huang, R., R. Masulis, and H. Stoll (1996) "Energy Shocks and Financial markets", Journal of Futures Markets, vol. 16, p. 1-27.

Huang, Y., and F. Guo (2007) "The role of Oil Price Shocks on China's Real Exchange Rate”, China Economic Review, vol. 18, p. 403-416.

Johansen, S. and Juselius, K. (1990) "Maximum Likelihood Estimation and inference on Cointegration with Application to the Demand for Money," Oxford Bulletin of Economics Statistics, vol. 52, p. 169-210.

Jones, C., and G. Kaul (1996) “Oil and Stock Markets”, Journal of Finance, vol. 51, p. 463-491.

Kilian, L. (2008) "Exogeneous Oil Supply Shocks: How Big are they and how much do they matter for the US Economy?", Review of Economics and Statistics, vol. 90(2), p. 216-240.

Kilian, L. (2008) "Exogeneous Oil Supply Shocks: How Big are They and How Much do They matter for the US Economy?", Review of Economics and Statistics, vol.90, p. 216-240

Lescaroux, F. and V. Mignon (2008) "On the Influence of Oil Prices on Economic Activity and other macroeconomic and Financial Variables”, OPEC Energy Review, vol. 32(4), p. 343-380.

Lin, C., C. Fang and H. Cheng (2011) "Relationship between oil price shocks and Stock market: an empirical analysis from Greater China", China Economic Journal, vol. 3(3), p.241-254.

Miller, J. and R. Ratti (2009) "Crude Oil and Stock Markets: Stability, Instability and Bubbles", Energy Economics, vol. 31(4), p. 559-568.

Nandha, M. and S. Hammoudeh (2007) "Systematic Risk, and Oil Price and Exchange Rate Sensitivities in Asia-Pacific Stock markets", Research in International Business and Finance, vol. 21, p. 326-341.

O’Neil, T. J., J. Penm and R.D. Terrell (2008) “The Role of Higher Oil Prices: A Case of Major Developed Countries”, Research in Finance, vol. 24, p. 287-299.

Pappetrou, E. (2001) “Oil Price Shocks, Stock Market, Economic Activity and Employment in Greece”, Energy Economics, vol. 23, p. 511-532.

Park, J. and R. A. Ratti (2008) "Oil Price Shock Markets in the US and 13 European Countries", Energy Economics, vol. 30, p. 2587-2608.

Sadorsky, P. (1999) “Oil Price Shocks and Stock Market Activity" Energy Economics, vol. 21, p. 449-469.

Yurtsever, C., and T. Zahor (2007) "Oil Price Shocks and Stock market in the Netherlands", Working paper, University of Groningen. 